\title{
La sociedad civil nicaragüense: sus organizaciones y sus relaciones con el Estado
}

Autor: Luis Héctor Serra Vázquez

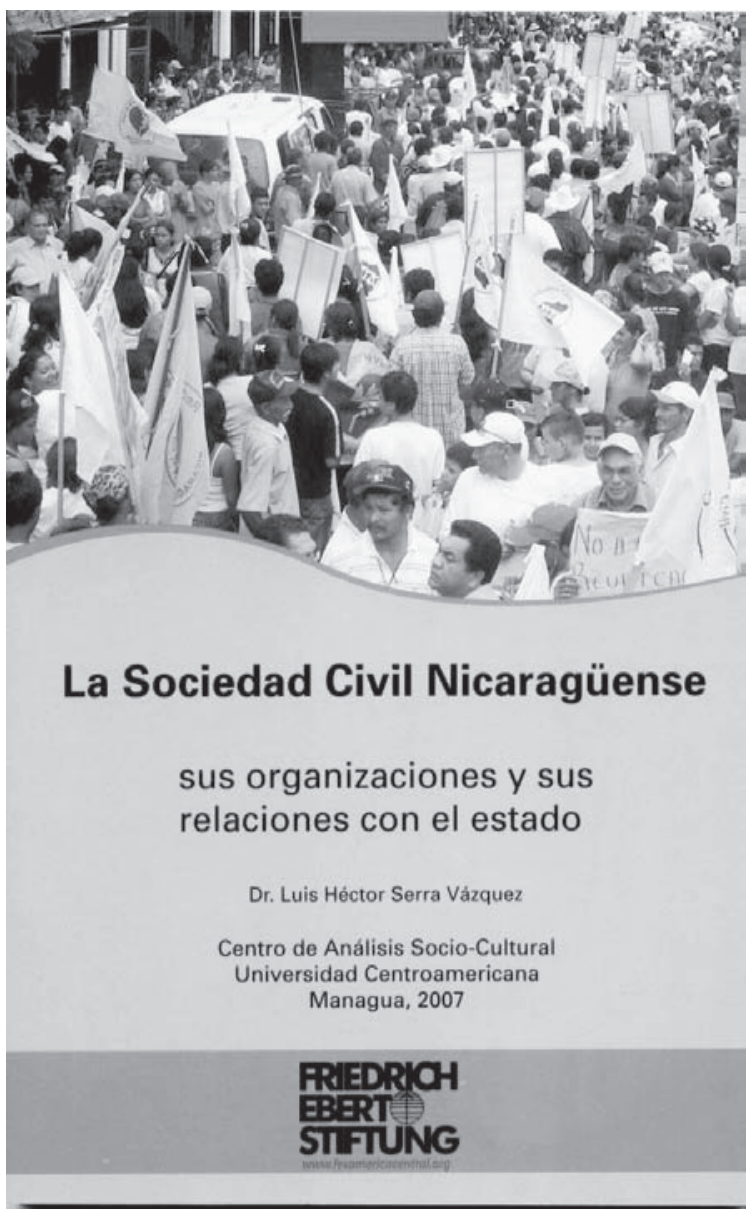

Este libro presenta un panorama del desarrollo alcanzado por las organizaciones de la sociedad civil y el rol que han jugado en la democratización del sistema político y en el desarrollo humano de Nicaragua. Teóricamente la sociedad civil es enfocada como un "Tercer Sector" basado en el principio de asociación solidaria, distinto del "Sector Estatal" regido por la lógica del poder y el control, y del "Sector del Mercado", basado en relaciones de competencia en búsqueda del lucro mercantil. El estudio aborda las interrelaciones de estos tres sectores en los "espacios de gobernanza" existentes en la Nicaragua contemporánea y los retos planteados por el nuevo gobierno del FSLN.

El Dr. Luis H. Serra Vázquez es investigador y profesor miembro del Centro de Análisis Sociocultural (CASC) de la Universidad Centroamericana. 